\title{
FIFA World Cup as a leading factor of sustainable development: a case of the Nizhny Novgorod region
}

\author{
Elena Kochkurova \\ Institute of Economics and Entrepreneurship \\ National Research University \\ Gagarin str. 23, 603950 Nizhny Novgorod \\ Privolzhsky Research Medical University \\ pl. Minin and Pozharsky, 10/1, 603950, Nizhny Novgorod \\ Russian Federation \\ e-mail: elenakochkurova@mail.ru \\ Tatiana Zykova \\ Institute of Economics and Entrepreneurship \\ National Research University \\ Gagarin str. 23, 603950, Nizhny Novgorod \\ Russian Federation \\ e-mail: tanya.5036@mail.ru
}

\begin{abstract}
The article reviews the influence of the 2018 World Cup heritage as a leading factor of the territorial sustainable development on the example of the Nizhny Novgorod region. The main objective of the study is to identify the positive and negative effects of hosting the FIFA World Cup on the tourist flow to the region and ensuring its leading development in the future. The international experience of hosting FIFA World Cup in other countries is under consideration. The positive and negative consequences of hosting the World Cup for the host country are covered as well. The short-term and long-term results of the 2018 World Cup for the region under investigation have been identified. The structure is proposed to study the heritage as the level of infrastructure, the level of hotel service, the level of development of the information and telecommunications infrastructure, as well as the influence of the 2018 World Cup on the image and informational fame of the city and the region. A statistical study of the growth of collective accommodation facilities for tourists, rooms and sports facilities has been carried out, and a sharp increase in the number of these facilities has been revealed. The qualitative changes in the infrastructure have been investigated, which at present corresponds to the world requirements. The expenses for construction and further maintenance of the largest infrastructure facilities of the Nizhny Novgorod region have been studied. The low economic efficiency of the further use of the World Cup heritage has been justified, while maintaining the existing tourist flow to the region. The regional tourist potential growth and the need to identify and develop new types of tourism to ensure sustainable development of the region have been ascertained. The growth of the qualitative and quantitative level of the basic elements of the tourist potential has been noted. The relationship between the preparation and hosting 2018 FIFA World Cup and the tourist potential growth of the Nizhny Novgorod region has been revealed
\end{abstract}

\section{Introduction}

In today's world, football takes on special significance for the formation of national self-awareness, assessment of the situation on the world arena of countries hosting FIFA World Cups and developing tourism in these countries. Cultivating a healthy lifestyle and playing sports become the main trend of social and economic development of many countries all over the world. Sport serves as a tool or a "hook" for leadership and promotion of positive results in the areas such as economic development, social integration, cultural cohesion, healthy lifestyles, education, gender equality, and reconciliation and peace building (Sherry et al. 2015; Vasylchak and Halachenko 2016; Abrhám and Wang 2017; Strielkowski and Shishkin 2017; Radovic et al. 2017; Mishenin et al. 2018). Expert studies show that sports organizations can play an important role in maximizing the results of tourism during major sporting events (Kennelly and Toohey 2014).

The international experience of hosting FIFA World Cups shows basically a positive trend in the impact on the social and economic development of host countries (Airey and Tribe 2013). However, it is necessary to distinguish between long-term and short-term influence (Han and Song 2017), where the first assumes the formation of the sports and tourism infrastructure that can continue to generate high income, the 
formation of a positive image and business reputation of host countries, which further attracts a high flow of tourists during international sporting events (Shevtsova et al. 2018). Short-term effect takes place when assessing the growth in the number of tourists visiting the country and regions during FIFA World Cup, the growth of GRP and GDP, based on the inflow of money from fans buying souvenirs and paying for tourist services in the region, etc (Doležal et al. 2015).

Despite the huge costs of building sports facilities, most countries estimate them as investments that can generate huge dividends (Gramlich 1994). In addition to the revenue from the sale of tickets, the stadium can become profitable if it becomes a national treasure, as happened with the Allianz Arena in Munich and Wembley Stadium in London. But, in developing countries (South Africa, Brazil), on the contrary, sports facilities built for FIFA World Cup are abandoned, because the activities carried out on them cannot ensure their sufficient loading.

\section{Quantitative and qualitative indicators}

The 2018 FIFA World Cup has become the most important event of the year and played a huge role in the social and economic development of Russia. In an interview with RIA Novosti FIFA President Gianni Infantino called the completed FIFA World Cup in Russia the best in history (Ria News 2018). The flow of tourists who visited Russia during 2018 FIFA World Cup, according to the estimates of Rosturizm, exceeded 5 million people, and 2.9 million out of them are foreign citizens. Historical analysis of attendance of FIFA World Cup for the period from 1994 to 2018 shows an incredible interest of foreign tourists in Russia, despite its negative image, cultivated by the Western countries. However, the average attendance per a game did not exceed the figures reached during FIFA World Cups, conducted by other countries, which is due to the large number of cities hosting the World Cup.

According to the Regnum information agency, the Nizhny Novgorod region was visited by about 355,000 people, about 150,000 of them are foreign tourists, and another 205,000 are Russians from other regions of this country. Hotel occupancy in the region reached $95 \%$ with the usual le vel of $45 \%$. Based on the results of 2018 World Cup games the additional income of business in the Nizhniy Novgorod region reached 8-9 billion RUB against the forecasted 6-7 billion RUB (Regnum 2018). As one can see, the shortterm results of the 2018 World Cup influence on the tourism development in the Nizhny Novgorod region are very impressive. But to have the full picture, it is necessary to consider other aspects of social and economic development, and tourism development in the Nizhny Novgorod region associated with the longterm outlook for the World Cup effect on this sector of national economy (Kochkurova and Zykova 2018).

The real tourist attractions are different in how they are developed and managed (Andergassen et al. 2017). Prospects for regional leadership depend on the level of tourist infrastructure, the level of hotel services, the level of development of information and telecommunications infrastructure, as well as related to the image of the region and the level of its popularity among Russian and foreign tourists. The popularity of the World Cup host cities has been assessed by the number of references to the name of the city in the context of the World Cup, as well as by a number of other quantitative and qualitative indicators. The study revealed that media do not pay enough attention to positioning the host cities as a brand, which reduces the level of their informational and advertising fame.

Additionally, the economic efficiency of investments in the preparation of the World Cup plays a big role (McCabe et al. 2012). For example, the Brazilian authorities spent about \$ 11 billion to finance the 2014 World Cup. Income from tourism and investments brought Brazil 13.5 billion in 2014 and an additional 90 billion are expected for the next 10 years (Egan 2014). For comparison, according to estimates of McKinsey experts, Russia spent \$13.2 billion on preparations for the World Cup this year. As for the effectiveness of investments, in monetary terms, Russia's GDP growth for the investment period 2013-2018 will amount to 867 billion RUB. Experts also highlight the long-term economic effect associated with the expected growth of tourism and development of the infrastructure. According to the preliminary estimates, it will amount to 150-210 billion RUB per year on the horizon of five years, the study report says (MK 2018; Statista 2018).

In the Nizhny Novgorod region, about 71 billion RUB were spent on preparing for the World Cup according to preliminary data published in the Arguments and Facts weekly newspaper. This amount includes 35 billon RUB from the Federal treasury, as well as funds from the regional budget and private investments. In total, about 50 facilities were built and reconstructed for the 2018 World Cup in the Nizhny Novgorod region, including the Nizhny Novgorod Arena stadium for 45,000 seats and the Strelka metro station. About 480 billion RUB have been spent on the construction of the Nizhny Novgorod Arena for 45,000 seats instead of the planned 100 billion RUB (AIF 2018). 


\section{Short-term results of the influence of the World Cup 2018 on regional leadership}

The 2018 World Cup stimulated the construction of hotels in both quantitative and qualitative terms. The growth rate of a number of common accommodation facilities increased by $45 \%$ in 2014 and by $12 \%$ in the subsequent years. The sharp increase in the number is due to changes in the rules of calculation: before 2014 only hotels have been taken into account, since 2014 - all accommodation facilities (i.e. hostels, mini-hotels, etc.) have been taken into account. 39 new hotels designed for 1133 rooms were built in the region for the World Cup. Some 5-and 4-star hotels meeting the requirements of FIFA have appeared in the region.

According to the experts, the average hotel occupancy in the Nizhny Novgorod region is 65\%. During the 2018 World Cup it increased to 95\%. However, given the fact that the guestroom stock has increased significantly in connection with the preparation for the World Cup, hotel occupancy should drop to 50\%, which certainly evidences about the inexpediency from the economic point of view to maintain such a number of common accommodation facilities.

The next aspect of the 2018 World Cup heritage is the development of infrastructure in the Nizhny Novgorod region. According to the Governor's assessment, for five years the region has passed a path equal to 25 years of development and the 2018 World Cup surely served as the catalyst for this development.

The main elements necessary for the 2018 World Cup were transport infrastructure elements (airports, railway communication, motor roads). On average, high-speed rail access has a positive effect on the regional tourism economy with a $12 \%$ increase in tourism revenues in the region (Luo 2017).

According to the experts in Madrid and London, there are 50-60 seats in stadiums per 1000 people and about 70 seats in Milan. In Russia, after finishing work on preparing for the World Cup, there are more than 100 seats in stadiums per 1000 people. The new Nizhny Novgorod stadium for 45 thousand seats will also allow expanding tourist destinations and attracting additional revenue to the treasury of the region.

According to the draft resolution of the Government of the Russian Federation regarding the approval of World Cup Heritage Concept, 1.17 billion RUB for the maintenance of the Nizhny Novgorod stadium will be allocated from the federal budget, 480.8 million from non-budgetary sources, and 45.5 million from the budget of the Nizhny Novgorod region (Nizhny Novgorod Heritage World Cup 2018).

The document provides an approximate cost estimation of operating the stadium based on the conduct of 20 home games in the Football Domestic League championship. In 2019, it will be 315.7 million rubles, in 2020 - 329.7 million, in 2021 - 343 million, in 2022 - 353.6 million, in 2023 - 364 million. Speaking about the ROI of the new stadium, it should be noted that after the 2018 World Cup the stadium will be involved approximately 320-340 days a year. In summer 2016, local authorities formed a plan of events for the arena after the World Cup. It is planned to hold up to 100 events per year, including 30 football games. According to the estimates of the authorities, in 3-4 years the stadium will be involved all year round hosting almost any events, including hockey matches (Vedomosti 2018).

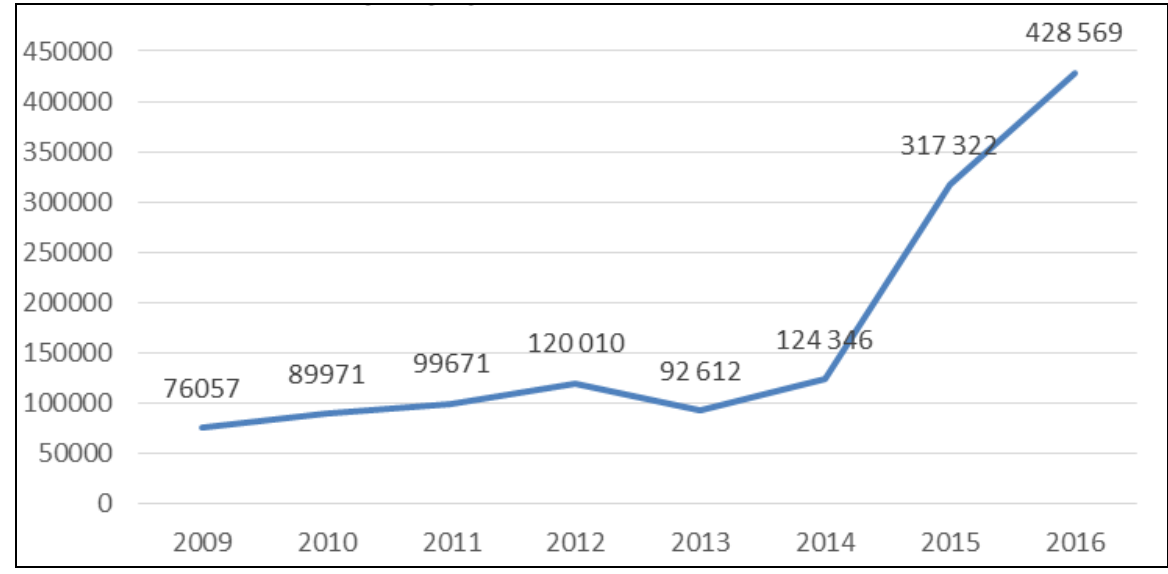

Fig.1. Number of people engaged in sports on a regular basis in the Nizhny Novgorod region Source: Ministry of Sport (2016)

The presence of a large number of sports infrastructure elements meeting the world level of quality, allows developing the direction of sports tourism. Sport-event tourism means organization and visiting of sporting events, these are unique tours that combine traditional rest and participation in the most spectacular events of the planet. 
The growth of funding for physical fitness and sports from all budget levels has allowed building the truly attractive sports facility, but it is not clear yet whether the developing in the region sports tourism will be able in future to attract enough funds to be efficiently maintained.

In addition to the stadium in the Nizhny Novgorod region, a training field was built in the Meshchera district and a sports base in the city of Bor, where the Uruguayan team lived and trained during the World Cup period. The construction of new sports facilities affected the growth of the number of people engaged in sports on a regular basis in the Nizhny Novgorod region.

Figure 1 above yields a sharp increase in the number of people involved in sports regularly after 2014, when preparations for the 2018 World Cup, the construction of new sports facilities and the reconstruction of the existing ones began. The increase in 2015 was $61 \%$, while the average increase in the period from 2009 to 2014 was $10-12 \%$. Perhaps the increased interest in sports and the corresponding quality infrastructure will help the development of sports and sports-events tourism in the Nizhny Novgorod region.

The construction of the new Strelka metro station and the reconstruction of roads and railways can certainly be assessed only as a positive heritage that will contribute to an increase in the tourist flow to the Nizhny Novgorod region. Moreover, lots of efforts were spent on solving the problem of waste sorting like in European cities. However, on completion of the World Cup the multicolored barrels stand unclaimed, because people are not accustomed to sorting wastes by materials which they are made from.

\section{Conclusions}

Overall, the obvious results of our research show that in the short term after the 2018 FIFA World Cup in Russia, the leadership positions of the Nizhny Novgorod region in the sphere of tourism were enhanced considerably. The flow of tourists has increased dramatically, the income of the region has increased even more than planned, and the region is now provided with the infrastructure and hotel facilities for many years to come.

In general, one can say that in the long run the 2018 World Cup heritage would make possible a jump in the development of the region, corresponding to 20-25 years of progressive growth. Sports infrastructure and hotel service facilities are qualitatively improved and correspond to the world level, which will attract more foreign and Russian tourists.

The other positive aspects of the World Cup also become apparent. For example, the Russian authorities were given the opportunity to arrange and host large-scale sports events of national importance. The tourist potential of the region has grown thanks to the development of infrastructure facilities and the growing popularity of the city brand among foreign tourists after visiting the 2018 World Cup. The downside is the low ROI of the existing 2018 World Cup heritage facilities and the need to maintain the same high tourist flow to the region as during the World Cup.

\section{References}

Abrhám J, Wang J (2017) Novel trends on using ICTS in the modern tourism industry. Czech Journal of Social Sciences, Business and Economics 6(1):37-43. doi: 10.24984/cjssbe.2017.6.1.5

AIF (2018). How much money was spent to prepare for the 2018 World Cup in the Nizhny Novgorod

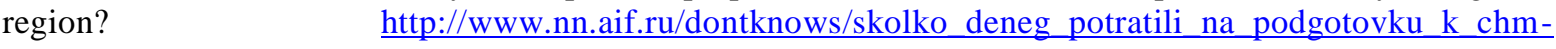
2018 _v nizhegorodskoy_oblasti Accessed 29 July 2018

Airey D, Tribe J, Developments in Tourism Research, $1^{\text {st }}$ edn. (Routledge, London, 2013), 268 p.

Andergassen R, Guido C, Figini, P (2017) The management of tourism destinations: A policy game. Tourism Economics 23(1):49-65. doi: 10.5367/te.2015.0496

Doležal J, Šnajdr J, Belás J, Vincúrová Z (2015) Model of the loan process in the context of unrealized income and loss prevention. Journal of International Studies 8(1):91-106. doi: 10.14254/2071$8330.2015 / 8-1 / 8$

Egan M (2014) South Africa's World Cup warning to Brazil. CNN Money. https://money.cnn.com/2014/06/09/investing/world-cup-south-africa-brazil/index.html Accessed 27 Aug 2018

Gramlich E (1994) Infrastructure Investment: A Review Essay. Journal of Economic Literature 32(3):1176-1196. 
Han L, Song H (2017) New Evidence of Dynamic Links between Tourism and Economic Growth Based on Mixed-Frequency Granger Causality Tests. Journal of Travel Research 57(7):899-907. doi: $10.1177 / 0047287517723531$

Kennelly M, Toohey K (2014) Strategic alliances in sport tourism: National sport organisations and sport tour operators. Sport Management Review 17(4):407-418. doi: 10.1016/j.smr.2014.01.001

Kochkurova E, Zykova T (2018) Research and assessment of recreational capacity of the Nizhny Novgorod region. Journal of Media Critiques 4(14):99-106. doi: 10.17349/jmc118200

Luo Y (2017) Special focus. Identifying the influential elements in the regional tourism economy. Tourism Economics 24(2): 185-186. doi: 10.1177/13548166177493

McCabe S, Minnaert L, Diekmann A (eds.), Social Tourism in Europe: Theory and Practice, $1^{\text {st }}$ edn. (Short Run Press, London, 2012), 217 p.

Ministry of Sport (2016) Statistics. http://www.minsport.gov.ru/function/wpcontent/uploads/2016/10/трудящиеся.pdf Accessed 29 Aug 2018

Mishenin Y, Koblianska I, Medvid V, Maistrenko Y (2018) Sustainable regional development policy formation: role of industrial ecology and logistics. Entrepreneurship and Sustainability Issues 6(1):329341. doi: 10.9770/jesi.2018.6.1(20)

MK (2018) Billions for Mundial: the cost of the 2018 World Cup was calculated by experts https://www.mk.ru/economics/2018/06/05/milliardy-na-mundial-stoimost-chm-2018-podschitalieksperty.html Accessed 21 July 2018

Nizhny Novgorod Heritage World Cup (2018). http://nn-atriot.ru/?id=30786 Accessed 26 July 2018.

Radovic D, Strielkowski W, Wang J, Cepel M, Rausser G (2017) Economic analysis of sustainable tourism: a case study of Nottingham. Transformations in Business \& Economics 16(2B):703-714

Regnum (2018) The income of the Nizhny Novgorod region from the World Cup 2018 exceeded the forecast by 3 billion rubles. https://regnum.ru/news/2446686.html Accessed 23 July 2018

Ria News (2018) The bests World https://rsport.ria.ru/russia2018_news/20180713/1139293687.html Accessed 29 Aug 2018

Sherry E, Schulenkorf N, Chalip L (2015) Managing sport for social change. Sport Management Review 18(1):1-5. doi: 10.1016/j.smr.2014.12.001

Shvetsova OA, Rodionova EA, Epstein MZ (2018). Evaluation of investment projects under uncertainty: multi-criteria approach using interval data. Entrepreneurship and Sustainability Issues 5(4): 914-928. doi:10.9770/jesi.2018.5.4(15

Statista (2018) Number of spectators at football World Cups from 1930 to 2014. https://www.statista.com/statistics/264441/number-of-spectators-at-football-world-cups-since-1930/ Accessed 18 July 2018

Strielkowski W, Shishkin A (2017) Paralympic Judo: Is there Evidence for Match Rigging among Athletes with Disabilities? Annals of Applied Sport Science 5(3):63-68. doi: 10.29252/acadpub.aassjournal.5.3.63

Vedomosti (2018) On the rentability of the new stadiums. https://www.vedomosti.ru/realty/articles/2015/09/21/609483-stadioni-nerentabelni-esli-otvechayutpotrebnostyam-mestnogo-rinka Accessed 28 July 2018

Vasylchak S, Halachenko A (2016) Theoretical basis for the development of resort services: regional aspect. International Economics Letters 5(2):54-62. doi: 10.24984/iel.2016.5.2.3 